still bound in our study of rocks of the crust by the involuntary contemplation of sea-level as it happens to be at any place to-day.

The whole work displays restraint on theoretical aspects of the subject, but this does not suggest timidity or confusion as the vast array of facts is excellently marshalled, being particularly well planned for easy reference ; the style of writing and the selection of illustrative photographs reveal great delicacy of touch which gives this most important work still further distinction.

N. F. H.

\title{
CORRESPONDENCE
}

\section{CRATANIOPHYLLUM, A NEW NAME FOR A CARBONIFEROUS CORAL GENUS}

SIR,-Lang, Smith, and Thomas [Index of Palaeozoic Coral Genera, Brit. Mus. (Nat. Hist.), 1940, p. 26] proposed the name Barbouria for Craterophyllum Barbour (Publ. Nebraska Geol. Surv., iv, (3), 1911, p. 38), a junior synonym of Craterophyllum Foerste, 1909, and of Craterophyllum Tolmachev, 1931. Dr. Dorothy Hill has pointed out to us, however, that Barbouria is pre-occupied by Barbouria Rathbun [Bull. Mus. comp. Zool. Harvard, liv, (15), 1912, p. 455], for a crustacean. We now propose

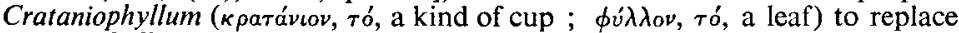
Craterophyllum Barbour nec Rathbun nec Tolmachev, the type species being C. verticillatum Barbour (op. cit., p. 38, pls. 1-4), probably from the horizon of the Oread Limestone (Pennsylvanian), of Nehawka, Cass County, Nebraska, U.S.A.

W. D. LANG.

H. Dighton Thomas.

Department of Palaeontology,

BRITISH MUSEUM (NATURAl History),

CromWell RoAD,

LONDON, S.W. 7.

8th July, 1957.

\section{A SLOW TEMPO OF DENUDATION CLAIMED FOR EASTERN AUSTRALIA}

Srr,-The average rate of lowering of the land surface by solution (chemical denudation) throughout the world is, according to data collected by Clarke $(1924$, p. 121) one foot in 30,000 years, or 2,000 feet in an interval extending back to the beginning of the Tertiary ( 60 million years). This takes no account of mechanical degradation, which cannot be negligible in a diversified landscape like that around Canberra, in eastern Australia. Noakes (1954, p. 128) confidently infers that at Canberra the erosional lowering (by chemical and mechanical denudation) during that time has been practically nil, though in valleys to the east it might amount to 100 feet.

Even though this applies to valley lowlands, and the hills bordering the lowlands have considerable relief, it may be taken to be applicable to the surface as a whole, if serious attention is to be paid to the claim (made by Noakes) that the general aspect of the landscape and particularly its relief have changed little since the Mesozoic (or even the Palaeozoic).

The hills immediately around Canberra have a relief of 800 to 1,000 feet, 
with land slopes as steep as $20^{\circ}$, which may be estimated from published photographs; and relief in the surrounding country amounts to thousands of feet. Yet Noakes claims that "the lineaments [major landscape features] ... seem to be legacies from the Palaeozoic", with fault-line scarps that separate them becoming higher " as erosion progressed" since that time. In other words, a single erosion cycle has not only been in progress since Palaeozoic times, but has not yet passed beyond the stage of early maturity characterized by waxing relief. An argument that the land must have remained low-lying "to escape deep erosion" between the Triassic and the Tertiary, or that it has remained "at or near base level ... since the Palaeozoic ", is of no significance in view of the existing strong relief, whether this be attributable to erosion during that interval or be assumed to have survived through it. It is not difficult to understand why the country has not been dissected to stronger relief, but the mystifying question is why strong relief which either was present initially or developed early in the cycle has not subsequently been destroyed by erosion which has been going on for 150 million years, whether the land remained low-lying or not.

C. A. CotTon.

\section{REFERENCES}

Clarke, F. W., 1924. The data of geochemistry, U.S. Geol. Sury. Bull., 770. NOAKES, L. C., 1954. "The Canberra region," in Canberra: a Nation's Capital, Sydney: Angus and Robertson, pp. 115-131.

\section{Manuka Avenue,}

LOWER HUTT,

New Zealand.

12th July, 1957.

\section{DETERMINATION OF [001] AXES IN MUSCOVITE}

SiR, - I have read with great interest the paper " Regional Study of Epidote, Mica, and Albite Fabrics of the Moines " by C. B. Crampton, which appeared in your issue of March-April, 1957. It is particularly interesting because the author has determined the fabric of epidote and albite, minerals which are rarely dealt with in petrofabric analyses. The author has also made a large number of determinations of muscovite [001] Axes, another rather neglected problem in structural petrology. On this part of the paper I would like to make the following comments.

1. The author seems to have little confidence in a diagram of muscovite [001] Axes, published by me in 1945, because it was "measured from a section perpendicular to the foliation " and "it is impossible to differentiate between the $Y$ and $Z$ axes within sections perpendicular to the foliation ".

The impossibility of differentiating between the $\mathrm{Y}$ and $\mathrm{Z}$ axes in muscovite grains having the [001] cleavage planes perpendicular to the section is, I hope, a well known fact to all who have made such determinations. If, however, the angle between cleavage plane and thin section is about 70 degrees or less, the differentiation can easily be made, provided the optic angle is not abnormally low. After having placed the $\mathrm{Y}$ or $\mathrm{Z}$ axis parallel to $\mathrm{A}_{4}$ ( $\mathrm{E}-\mathrm{W}$ horizontal axis) on the universal stage, the stage is rotated $45^{\circ}$ about the $\mathrm{A}_{5}$ (microscope axis), and the change in birefringence by rotation about $A_{4}$ is observed. If, for instance, 340 is read on the $A_{4}$ scale when the [001] plane is vertical, a rotation to 50 would bring one of the optic axes parallel to the tube of the microscope, if $Y$ is parallel to $A_{4}$. If $Z$ is parallel to $\mathrm{A}_{4}$, the same rotation would bring parallel to the tube a direction in the $\mathrm{XY}$ plane which is 30 degrees from $\mathrm{X}$. If by rotation on $\mathrm{A}_{4}$ the $\mathrm{X}$ direction can be brought parallel to the tube, a very low birefringence is usually observed. Besides the angle between the observed direction and the [001] 